\title{
David McPherson*
}

\section{Traditional Morality and Sacred Values}

DOI: $10.1515 /$ auk-2017-0003

\begin{abstract}
This essay gives an account of how traditional morality is best understood and also why it is worth defending (even if some reform is needed) and how this might be done. Traditional morality is first contrasted with supposedly more enlightened forms of morality, such as utilitarianism and liberal Kantianism (i.e., autonomy-centered ethics). The focus here is on certain sacred values that are central to traditional morality and which highlight this contrast and bring out the attractions of traditional morality. Next, this essay explores and offers support for the convergence thesis to which traditional morality, understood as common morality, is committed. This thesis states that although there are diverse moral traditions, insofar as they are in good order we should expect them to converge upon a common or universal morality, even if there remain some differences in the details. The defense of this thesis provides justification for the validity of traditional morality as it suggests an objective basis.
\end{abstract}

Keywords: Traditional morality, sacred values, the sacred, ethical convergence

“The individual is foolish [...] but the species is wise.” (Burke 2009[1782], 398)

"All fixed, fast-frozen relations, with their train of ancient and venerable prejudices and opinions, are swept away, all new-formed ones become antiquated before they can ossify. All that is solid melts into air, all that is holy is profaned [...].” (Marx/Engels 2000[1848], 248)

\section{Introduction}

In this essay I want to get clear on the idea of 'traditional morality'. More specifically, I want to give an account of how it is best understood and also why it is worth defending (even if some reform is needed) and how this might be done.

When the idea of traditional morality is mentioned in academic moral philosophy it is often as the contrast case to some supposedly more 'enlightened' form

*Corresponding Author: David McPherson, Department of Philosophy, Creighton University, 2500 California Plaza, Omaha, Nebraska, USA 68178, e-mail: davidmcpherson@creighton.edu 
of morality that is said to supersede it. For instance, the utilitarian Peter Singer writes:

\footnotetext{
"The traditional ethic is still defended by bishops and conservative bioethicists who speak in reverent tones about the intrinsic value of all human life, irrespective of its nature or quality. But, like the new clothes worn by the emperor, these solemn phrases seem true and substantial only while we are intimidated into uncritically accepting that all human life has some special dignity or worth.” (Singer 1995, 4)
}

I think we can in fact make headway in understanding the idea of traditional morality by considering its contrast with supposedly more enlightened forms of morality, such as utilitarianism and liberal Kantianism (i.e., autonomy-centered ethics). I will take this up in the next section, where I will also aim to show the attractions of traditional morality in comparison to these 'enlightened' forms of morality. I will focus especially on the importance of certain 'sacred values' (or 'sacred goods') within traditional morality. Sacred values are certainly not the only type of values within traditional morality, but they are central to it and they highlight the difference with utilitarianism and liberal Kantianism.

We will see that the adjective 'traditional' in 'traditional morality' can be understood in two ways, which on the face of it might seem to be at odds. On the one hand, traditional morality can be understood as common morality. To be more precise: the adjective 'traditional' comes in here because it refers to a form of morality that has been common throughout human history but which has come under threat in the modern world because of the 'Enlightenment project' (as Alasdair MacIntyre calls it) of seeking to justify morality apart from any appeal to an inherent moral teleology, i.e., to objective (or 'substantive') moral purposes to which we must align our lives if we are to achieve our fulfillment as human beings (see MacIntyre 2007[1981], chs. 4-6).

On the other hand, the adjective 'traditional' in 'traditional morality' can refer to some particular moral tradition (i.e., a specific body of moral wisdom that has been built up and 'handed down' over the generations). This has also been challenged by the 'Enlightenment project', which brought us moral theories such as the various versions of utilitarianism and Kantianism that seek to offer a decision procedure (e.g., the principle of utility, the requirement of universalization, the veil of ignorance, etc.) that prescinds from ordinary moral experience and from any particular tradition-informed moral community (what Hegel calls Sittlichkeit).

Traditional morality can then refer to common morality or a particular moral tradition. Are these at odds? I want to argue that they are not, and indeed any adequate form of traditional morality needs to incorporate both of these understandings. In short, the claim is that we must always access the universal via the particular. Traditional morality, as understood here, is thus committed to a con- 
vergence thesis: this states that although there are diverse moral traditions, insofar as they are in good order we should expect them to converge upon a common or universal morality, even if there remain some differences in the details. This thesis also provides justification for the validity of traditional morality as it suggests an objective basis. I will seek to offer support for this thesis in the third and final section.

\section{2 'Traditional' vs. 'Enlightened' Moralities}

Let us begin to build up a picture of traditional morality by considering its contrast with supposedly more enlightened forms of ethics, viz., utilitarianism and liberal Kantianism (i.e., autonomy-centered ethics). Stuart Hampshire brings out well the contrast between utilitarianism and traditional (i.e., common) morality in the following passage:

"[There] is one feature of familiar moralities which utilitarian ethics famously repudiates, or at least makes little of. There are a number of different moral prohibitions, apparent barriers to action, which a man acknowledges and which he thinks of as more or less insurmountable [...]. [In] addition to certain fairly specific types of killing, certain fairly specific types of sexual promiscuity, certain takings of property, there are also types of disloyalty and of cowardice, particularly disloyalty to friends, which are very generally, almost universally, forbidden and forbidden absolutely. They are forbidden as being intrinsically disgraceful and unworthy, and as being, just for these reasons, ruled out: ruled out because they would be disgusting, or disgraceful, or shameful, or brutal, or inhuman, or base, or an outrage." (Hampshire 1983, 87-89)

In other words, for the utilitarian there is literally 'nothing sacred'. There are no actions that are absolutely ruled out; anything is permissible so long as it serves to maximize pleasure or preference-satisfaction and minimize pain or dissatisfaction.

This is made abundantly clear in the work of Peter Singer, who, e.g., is willing to countenance the intentional killing of what he calls "defective infants", provided a quality of life assessment determines that their lives are not "worth living" (see Singer 1993, chs. 4-7). ${ }^{1}$ As we saw above, he regards those who "speak in reverent tones about the intrinsic value of all human life" and thus believe that we should never intentionally kill innocent human beings as being essentially super-

1 The language of 'defective infants' was used in the first edition of Singer's Practical Ethics, but he switched to speaking about 'disabled infants' in the second edition. For more on this, see Laing 1997. 
stitious and irrational. Singer realizes that his claims are likely to be shocking to many, but he thinks that is no reason to reject them since he believes his position is ultimately the more rational and humane one. However, it is highly questionable whether a view that can countenance the intentional killing of 'defective infants' and a host of other forms of human killing in the name of 'quality of life' or the 'greatest happiness for the greater number' is really to be considered the more humane position. It fails to appreciate how deep the experience of the 'special dignity' or sanctity of all human life goes in defining or 'building up' a common moralized conception of humanity. ${ }^{2}$

This is particularly true in cultures with exemplars of saintly love, where, as Raimond Gaita discusses, "there has developed a language of love whose grammar has transformed our understanding of what it is for a human being to be a unique kind of limit to our will” (Gaita 1998, 24). Our eyes are opened here (and in other ways) ${ }^{3}$ to the sacredness or special dignity of all human life, which often involves a sense of mystery. As Cora Diamond puts it:

"The sense of mystery surrounding our lives, the feeling of solidarity in mysterious origin and uncertain fate: this binds us to each other, and the binding meant includes the dead and the unborn, and those who bear on their faces 'a look of blank idiocy', those who lack all power of speech, those behind whose vacant eyes there lurks a 'soul in mute eclipse'.” (Diamond 1991, 55) ${ }^{4}$

This sense of mystery or sacredness or special dignity surrounding human life often stands behind the expectation of care for the young, the old, and the disabled, and of proper treatment of the dead, and the prohibition of killing innocent human beings (no matter their age or ability).

If there really is something here to which we should be responsive, then the failure to be properly responsive has to be attributed to a lack of a proper ethical

2 In regard to ‘building up' a moralized view of humanity, Cora Diamond writes (contra Singer): "[It] is not out of respect for the interests of beings of the class to which we belong that we give names to each other, or that we treat human sexuality or birth or death as we do, marking themin their various ways-as significant or serious. And again, it is not respect for our interests which is involved in our not eating each other. These are all things that go to determine what sort of concept 'human being' is. [...] The ways in which we mark what human life is belong to the source of moral life.” (Diamond 1978, 469-471)

3 Cora Diamond, e.g., appeals to works of literature, such as the novels of Dickens and Dostoevsky, in order to imaginatively bring into view the special value of humanity (see Diamond 1991, 42-59).

4 Joseph Conrad speaks of "the solidarity in mysterious origin, in toil, in joy, in hope, in uncertain fate, which binds men to each other and all mankind to the visible world" (quoted in Diamond 1991, 50). 
formation that would open our eyes to this domain of the sacred (I will later return to discuss this issue of ethical formation further), and/or to ideological and/or moral corruption that causes a kind of moral blinding. Gaita suggests something like the latter with regard to "those practical philosophers"-and he surely has Singer in mind here- "who have been in the forefront of the argument to relax the conditions under which it is permissible to kill people": they have "no sense of awe in the face of the questions they have raised, and no sense of humility in the face of the traditions they condescendingly dismiss. They are aggressively without a sense of mystery.” (Gaita 1991, 322)

Although Hampshire does not use the language of the sacred, I believe something like a sense of sacred value is behind his remarks about outrage, brutality, and inhumanity, and he does remark that "these ideas have often been associated with impiety" (Hampshire 1983, 89)..$^{5}$ As it pertains to traditional morality, sacred value is that which is reverence-worthy and which places strong normative demands upon us for attitudes and actions that are appropriately responsive to this reverence-worthiness. Particularly important are demands of inviolability, and where sacred value is violated, we righty feel deep horror and outrage. ${ }^{6}$ So the contention here is that a sense of sacred value is often implicit in the common experience of horror at various forms of human killing, and the explicit articulation of it is needed to make adequate sense of the wrong of these horrors. In other words, the wrong of intentionally killing innocent human beings cannot be explained merely in terms of 'robbing' someone of future enjoyable experiences or its threat to social order or even its violation of autonomy; the horror is at the

5 On this theme, see Diamond's 'The Problem of Impiety' (Forthcoming).

6 This account contrasts with Jonathan Haidt's view of sanctity, which is one of his five moral foundations (the others are care, fairness, loyalty, and authority) and which he interprets in terms of a visceral disgust response that has an evolutionary backstory involving "the need to avoid pathogens, parasites, and other threats that spread by physical touch or proximity" (Haidt 2012, 148). Haidt writes: "The Sanctity foundation makes it easy for us to regard some things as 'untouchable', both in a bad way (because something is so dirty or polluted we want to stay away) and in a good way (because something is so hallowed, so sacred, that we want to protect it from desecration). If we had no sense of disgust, I believe we would also have no sense of the sacred." (149) He later writes of this sense of disgust: "It makes it possible for people to invest objects with irrational and extreme values [...] which are important for binding groups together.” (154) This view neglects the perception of reverence-worthiness that is central to my account of sacred values. Although Haidt thinks that a sense of the sacred has a social usefulness (and it would fit with an appeal to common human needs as a way of justifying traditional morality; see the next section for more on this), his reductive account of it, if accepted, would have a deflationary effect on the experience of sacred values. Cf. Friedrich Hayek's evolutionary defense of traditional morality in Hayek 1988. 
taking of human life itself, the sense of something sacred or profoundly precious having been violated.

In her essay 'Modern Moral Philosophy', Elizabeth Anscombe remarked (at a time when utilitarianism was dominant) that the "differences between the wellknown English writers on moral philosophy from Sidgwick to the present day are of little importance", because, in essence, they are all consequentialists of some form and thus show a "corrupt mind" (Anscombe 1958, 1, 17). She writes:

\begin{abstract}
"The overall similarity is made clear if you consider that every one of the best known English academic moral philosophers has put out a philosophy according to which, e.g., it is not possible to hold that it cannot be right to kill the innocent as a means to any end whatsoever and that someone who thinks otherwise is in error. [...] Now this is a significant thing: for it means that all these philosophies are quite incompatible with the Hebrew-Christian ethic. For it has been characteristic of that ethic to teach that there are certain things forbidden whatever consequences threaten, such as: choosing to kill the innocent for any purpose, however good [...]. [It] would [take] a certain provinciality of mind not to see this incompatibility as the most important fact about these philosophers, and the differences between them as somewhat trifling by comparison." (9-10)
\end{abstract}

The 'Hebrew-Christian ethic', as Anscombe understands it, is essentially a theistic natural law ethic. But it is not just the Hebrew-Christian ethic that teaches that "there are certain things forbidden whatever consequences threaten". For instance, Socrates in Plato's Gorgias says that it is better to suffer evil than to do evil (469c). Likewise, Aristotle remarks: "there are some things we cannot be compelled to do. Rather than do them we should suffer the most terrible consequences and accept death.” (NE III.1, 1110a26-28) He mentions the act of killing one's own mother as such a case. Elsewhere he says:

"not every action or feeling admits of the mean. For the names of some automatically include baseness-for instance, spite, shamelessness, envy [among feelings], and adultery, theft, murder among actions. For all of these and similar things are called by these names because they themselves, not their excesses or deficiencies, are base. Hence in doing these things we can never be correct, but must invariably be in error.” (NE II.6, 1107a10-15)

The claim here (following Anscombe) is that the sense that there are some things that are absolutely forbidden is common to ordinary moral experience, provided one has received a proper upbringing and has not been ideologically and morally corrupted by bad moral theories (which is what I take Anscombe to mean in her provocative 'corrupt mind' charge). ${ }^{7}$

7 See Gaita 1991, chs. 2 \& 17 for a sympathetic discussion of Anscombe’s 'corrupt mind' charge. 
So far we have focused on the contrast of traditional morality with utilitarianism, but what about liberal Kantianism, i.e., autonomy-centered ethics? It is important first to note that Kant himself in fact can be read as an advocate of traditional morality and as trying to provide it with what he took to be the most rational footing. ${ }^{8}$ One only need consider his traditional (or quasi-traditional) views on homicide, suicide, stealing, lying, sexuality, etc. Although his first formulation of the categorical imperative-the universalization requirement-may appear proceduralist (or constructivist) in a way that is at odds with the substantive moral judgments of traditional morality, Kant's second formulation of the categorical imperative-the respect for persons (i.e., humanity) requirement-can be read as appealing to a substantive moral judgment about the intrinsic dignity of human beings in virtue of their capacity for rationality and moral agency in order to ground his defense of traditional moral positions.

However, later Kantians have developed a weaker or more liberal version of Kant's idea of respect for persons, where this is interpreted primarily in terms of respect for individual autonomy, which also requires certain proceduralist rules of fairness. This view does contrast with utilitarianism in ruling out, e.g., many forms of human killing, however it typically allows for some forms of human killing-for the sake of individual autonomy-that are absolutely prohibited from the perspective of traditional morality: e.g., abortion and physician-assisted suicide. ${ }^{9}$ Here there is a denial of the traditional doctrine of the sanctity of human life (or the life as a sacred 'gift' view) according to which there is an absolute requirement that we ought never to kill intentionally any innocent human being ${ }^{10}$-no matter the ability or disability or the stage of development from conception to natural death-in virtue of all human beings possessing the same profound intrinsic dignity. ${ }^{11}$

8 See the titles of the first two sections of Kant's Groundwork for an indication of this intent. For a more recent Kantian defense of traditional morality, see Donagan 1977.

9 On abortion, see, e.g., Thomson 1971; on physician-assisted suicide, see, e.g., Dworkin et al. 1997. For defenses of the traditional view on these matters, see, e.g., Keown 2012 and Oderberg 2000a-b.

10 Here 'innocent' means that one is not intentionally threatening lethal or some other grave harm.

11 Ronald Dworkin is an interesting case of a liberal Kantian who explicitly endorses the idea of sacred values. However, since people disagree on sacred values, he wants to privatize the allegiance to them and give precedence to autonomy (i.e., individual conscience) in political morality and public policy. This is of course very different from the traditional view, which would say that any sacred value that didn't have precedence over autonomy is not in fact a sacred value. See Dworkin 1993, esp. 13-15, 25-26, 28, 32-34 \& ch. 3 ('What is Sacred?'); see also Dworkin 2013. 
We also see the opposition to traditional morality if we consider another domain besides life and death where a sense of sacred value arises (which was also mentioned by Hampshire): viz., human sexuality. On the standard (Kantian) liberal sexual ethic there is nothing of inherent moral significance about human sexuality and only general moral rules apply. Thus, sex can be seen as being on par with a business relationship in which each party consents to exchange a 'commodity' for mutual benefit and where they are expected to live up to their side of the bargain (see Goldman 1977, 280-283; cf. Primoratz 2001). The liberal sexual ethic is essentially a consent-only model of sexual ethics. On such a view there is nothing wrong with casual sex, promiscuity, prostitution, sadomasochism, pornography, and so forth, so long as everyone involved gives their consent. In contrast to the liberal idea of the sexual commodity, traditional morality affirms the idea of the sexual sacrament according to which there is something inherently sacred or profoundly significant about human sexuality (see Scruton 1996, 134).

This can be seen, e.g., in the vow of erotic love, which is ritually expressed in marriage vows. Roger Scruton writes:

"A vow of marriage creates an existential tie, not a set of specifiable obligations. [...] [The] world of vows is a world of sacred things, in which holy and indefeasible obligations stand athwart our lives and command us along certain paths, whether we will or not. [...] [The] theory of marriage as a sacrament captures a prior sense that something similar is true of erotic love.” (Scruton 2006, 88)

Unlike lust (which is common in animal life), erotic love (which is distinctively human) involves a loving intention towards a particular human being with whom one desires to be sexually united in an intimate bond and where the beloved is regarded as irreplaceable. Because human beings are sacred (i.e., have special dignity) and sexuality is an integral part of who we are, the intimate bond of erotic love is properly seen as a sacred bond. ${ }^{12}$ Furthermore, erotic love has an inherent 'nuptuality': it tends towards permanence and exclusivity. ${ }^{13}$ In other words, when

12 Traditionally the link between sexuality and the generation of new life has also been seen as imbuing human sexuality with a sense of the sacred or the profoundly significant. Consider the following remarks by Anscombe: "There is no such thing as a casual, non-significant sexual act. [...] Those who try to make room for sex as mere casual enjoyment pay the penalty: they become shallow. [...] They dishonour their own bodies; holding cheap what is naturally connected with the origination of human life." (Anscombe 2008, 186) She says that the perception of dishonour here involves a "mystical perception" (187), which I would call a sense of sacred value. Anscombe does tend to neglect or under-emphasize that there is also profound significance in the unitive aspect of erotic love.

13 See Scruton 1986, 339; cf. Plato: “love is wanting to possess the good forever” (Symposium 206a). 
we really love someone erotically we do not want to live without them, indeed we want to bind our lives together, and this also demands exclusivity as proper to the profound intimacy of the erotic loving relationship (and hence jealousy can be an appropriate emotional response to threats to this intimate relationship). Thus, erotic love finds its proper fulfillment in the vow of marriage.

One of the most important aspects of the traditional sexual ethic is that it aims to ennoble and humanize sexual desire by transforming mere lust into erotic love, which, at its best, is one of the highest modes of human experience. The traditional ethic does so through cultivating virtues such as chastity (i.e., right intention in sexual desire), fidelity, modesty, and erotic love itself. Additionally, it also places strong taboos around certain aspects of human sexuality. For advocates of the sexual revolution, these taboos are of course seen as repressive and unhealthy and so to be overthrown. However, while some reform of traditional sexual mores may be called for, insofar as one seeks to throw off all taboos regarding human sexuality (save that against non-consensual sex), this seems to be a prime case of 'throwing the baby out with the bathwater'. Some of these taboos-e.g., against casual sex, promiscuity, adultery, pornography, prostitution, etc.-are meant to protect what is best in human sexuality: viz., erotic love and its vow. Other taboos are concerned with avoiding what is worst: viz., rape and other forms of sexual violence.

Here we also see the importance of recognizing sacred value in human sexuality. For the liberal, consent-only model of sexual ethics, rape and other forms of sexual violence are wrong because they violate consent (i.e., individual autonomy). While this is certainly true, what the standard (Kantian) liberal sexual ethic cannot explain-due to its view that human sexuality has no inherent moral significance-is why rape is so wrong, indeed, why it is one of the worst wrongs that one human being can do to another, and it is certainly worse than, say, a 'health nut' forcing someone to eat an apple at gun point (see Scruton 1996, 133 and Benatar 2002). I think the same is true for the utilitarian view, given the exclusive focus on pleasure and pain (or preference-satisfaction and -dissatisfaction). What we need is the language of the sacred (or something like it) in order to articulate our experience of the wrong of rape and other forms of sexual violence, since there is rightly a sense of desecration of something sacred (i.e., reverence-worthy) in such cases. In short, it seems that we need something like the traditional sexual ethic-even if we don't embrace everything that has fallen under that headingbecause of its strong taboos that are meant to recognize and protect what is sacred (or profoundly significant) in human sexuality and to prevent it from becoming a mere object of use.

In the foregoing I have focused on some of the most contested issues between traditional morality and supposedly more enlightened forms of morality. I have 
tried to show that traditional morality does a better job of accounting for common moral experiences in matters of life, death, and sexuality. I have focused on certain sacred values because they are of central importance for traditional morality and they highlight the contrast with supposedly more enlightened forms of morality and the attractions of traditional morality. However, there are other kinds of values that are also recognized, such as noble (or admirable) values, which come into play, e.g., with an account of virtues and vices. Traditional morality seeks to attend to the common human fund of moral experience and conserve whatever is good in this experience. In this way it can be seen as an anti-theory approach to morality. This does not mean that philosophy does not have a role to play, but its role consists primarily in overcoming inconsistencies, clarifying and articulating our inchoate sense of things, and offering justification. The sort of 'theory' that traditional morality is against is that which seeks to offer a decision procedure (e.g., the principle of utility, the requirement of universalization, the veil of ignorance, etc.) that prescinds from ordinary moral experience and from any particular tradition-informed moral community.

A particularly problematic feature of such moral theories is their reductionism: they reduce the complexity of our ordinary moral experience, especially in regard to substantive moral judgments about various good and bad things that define for us the good life (see Williams 1985, 15-18). They do so by offering a basic principle or decision-procedure that is supposed to take precedence in the moral life. However, they do not prescind entirely from substantive moral judgments, since accepting the precedence of their basic principle or decision-procedure requires a substantive moral judgment about, e.g., the goodness of universal benevolence (in the case of utilitarianism) or the importance of autonomy (in the case of liberal Kantianism) ${ }^{14}$

Even if we grant that these are good things, why think that they are the only good things or that they should take precedence? According to traditional morality, benevolence (or charity) is a virtue, but not the only one. There are other virtues such as loyalty and justice with which it must be made consistent. Likewise, in certain respects autonomy is indeed a good, though it is also constrained by other goods, such as virtue and the value of human life. Moreover, if there are no ends of choice that are of great importance and can place constraints on our choices, then this seems to deflate our sense of the importance of choice. David Wiggins writes:

"[If] we are not ready to scrutinize with any hesitation or perplexity at all the conviction (as passionate as it is groundless, surely, for no larger conception is available that could vali-

14 See Taylor 1989, ch. 3 ('The Ethics of Inarticulacy’). 
date it) that everything in the world is in principle ours or there for the taking; then what will befall us? Will a new disquiet assail our desires themselves, in a world no less denuded of meaning by our sense of our own omnipotence than ravaged by our self-righteous insatiability?” (Wiggins 2001, 242)

Thus defenders of traditional morality typically see supposedly more enlightened forms of morality as mere 'fragments' torn from the larger whole of traditional morality. As C. S. Lewis puts it in his defense of traditional morality (or the Tao, as he calls it):

"What purports to be new systems [of value] [...] all consist of fragments from the Tao itself, arbitrarily wrenched from their context in the whole and then swollen to madness in their isolation, yet still owing to the Tao and to it alone such validity as they possess. [...] The rebellion of new ideologies against the Tao is a rebellion of the branches against the tree: if the rebels could succeed they would find that they have destroyed themselves." (Lewis 1944, 43-44) $)^{15}$

\section{Convergence}

In discussing 'traditional morality', rather than traditional moralities, I have been supposing that there is a common morality that particular moral traditions converge upon insofar as they are in good order. If this were indeed the case, then it would also provide justification for the validity of traditional morality as it suggests an objective basis. Regarding this issue, Lewis writes:

"If we lump together, as I have done, the traditional moralities of East and West, the Christian, the Pagan, and the Jew, shall we not find many contradictions and some absurdities? I admit all this. Some criticism, some removal of contradictions, even some real development, is required. [...] [The] Tao admits of development from within.” (Lewis 1944, 45)

Even though there may be some differences between traditional moralities (hence the use of the plural) and even if there is required some further refinement, what is important here is what is shared in common, which are the sort of things mentioned by Hampshire above (e.g., absolute or near absolute prohibitions on "certain fairly specific types of killing, certain fairly specific types of sexual promiscuity, certain takings of property, [and certain] types of disloyalty and of cowardice,

15 A similar 'fragments' (or 'survivals') thesis is advanced in Anscombe 1958 and MacIntyre 2007 [1981]. 
particularly disloyalty to friends", etc.), and which distinguish them from supposedly more enlightened forms of morality.

Traditional morality relies on 'the tried and true'. The conjunction is important "because the tried alone may have little in its favor and much against it and because the true needs to be tried, and tried again, to be shown to be true" (Kekes 1998, 5). Traditional morality claims that there is a body of moral wisdom (expressed in traditionally endorsed taboos, manners, and virtues) that has been built up over the ages in cultures that are in good working order in dealing with fundamental facets of the human condition (e.g., life, death, sexuality, procreation, sociality, vulnerability, etc.). Although there might be cause to reform certain aspects of this inherited moral wisdom-as Lewis says, "the Tao admits of development from within"-it is foolish to think that we can completely discard it and try to 'reinvent the wheel' in the moral life. As the first epigraph puts it: "The individual is foolish [...] but the species is wise."

But do we have good reason to affirm what I have called the convergence thesis? Consider Bernard Williams's challenge to this thesis. Williams thinks that in science there can be convergence on "how things (anyway) are" but he does not think there is a "convergence of reflective ethical thought on ethical reality in even a distant analogy to the scientific case" (Williams 1985, 139, 152). Indeed, he thinks that reflection tends to undermine purported claims to ethical knowledge, especially in regard to "thick ethical concepts"-e.g., sanctity, loyalty, courage, honesty, kindness, cruelty, brutality, etc.-that are seen as "world-guided and actionguiding" and are important in traditional morality. ${ }^{16}$ This destruction of purported ethical knowledge often occurs in traditional (or what Williams calls "hypertraditional") societies as they become more reflective and thus "become conscious of ethical variation and of the kinds of explanation it may receive" (159). What reflectiveness can reveal to us, he elsewhere suggests, is the "radical contingency" of our ethical beliefs, where they are seen as entirely dependent on the contingencies of our personal, cultural, and evolutionary histories and so "they might have been different from what they are" (Williams 2002, 20). Williams writes: "This sense of contingency can seem to be in tension with something that our ethical ideas themselves demand, a recognition of their authority." (21)

Williams thinks that the most comprehensible attempt to provide an objective grounding for morality is through appeal to common human needs ${ }^{17}$ (and related desires and emotional responses); but he does not think even this is likely to be

16 On reflection destroying purported ethical knowledge, see Williams 1985, 142-148, 158-159, 163-164, 167-170, 199-200; on 'thick ethical concepts', see 129-130, 140-148; the quotation is at 141.

17 I take it that a 'need' here pertains to one's flourishing or fulfillment. 
successful because "such considerations will radically underdetermine the ethical options even in a given social situation”:

"Any ethical life is going to contain restraints on such things as killing, injury, and lying, but those restraints can take very different forms. Again, with respect to the virtues, [...] we only have to compare Aristotle's catalogue of the virtues with any that might be produced now to see how pictures of an appropriate human life may differ in spirit and in the actions and institutions they call for. We also have the idea that there are many and various forms of human excellence which will not all fit together into [...] one harmonious whole, so any determinate ethical outlook is going to represent some kind of specialization of human possibilities. [...] The project of giving to ethical life an objective and determinate grounding in considerations about human nature is not, in my view, very likely to succeed." (Williams 1985, 153; cf. ch. 3)

I think Williams overplays here the extent of the underdetermination of human nature for ethics. In response to Williams, John Cottingham writes: "there is good reason to suppose that our species has remained biologically stable for many millennia. And certainly the human beings with whom Aristotle or the Buddha or Jesus were concerned were, in all respects relevant to biological flourishing, pretty much identical with us." (Cottingham 2009, 27) He acknowledges that there are of course differences across cultures but says: "diverse cultures [are] differing vehicles for the development of a common humanity, manifested in deep underlying common needs and desires-for physical security, for protection against vulnerability, for the development of personal relationships, for love and affection and family loyalty, and so on" (31). And so if we consider Aristotle's catalogue of the virtues it would seem, contra what Williams says in the above passage, that anyone concerned with leading a fulfilling life would have reason to cultivate many of these virtues: e.g., courage, moderation, generosity, friendship, etc. We can say something similar with respect to the restraints on killing, injury, lying, etc. Indeed, in light of our common human needs and related desires and emotional responses, we can see why across most if not all cultures there are absolute or near absolute prohibitions on "certain fairly specific types of killing, certain fairly specific types of sexual promiscuity, certain takings of property", and on certain types of "disloyalty and of cowardice, particularly disloyalty to friends".

Such virtues and prohibitions, I have suggested, are part of the tried and true moral wisdom that has been built up over the ages in addressing fundamental facets of the human condition (e.g., life, death, sexuality, procreation, sociality, vulnerability, etc.) and they enable a well-lived life. Williams in fact on occasion seems to acknowledge this 'tried and true' moral wisdom as offering the most reasonable path for living a good life. At one point he writes: 
"We wish [...] to bring up children to share some of these ethical, as of other cultural, conceptions, and we see the process as good not just for us but for our children, both because it is part of our conception of their well-being and also because, even by more limited conceptions of happiness or contentment, we have little reason to believe that they will be happier if excluded from the ethical institutions of society. Even if we know that there are some people who are happier, by the minimal criteria, outside those institutions, we also know that they rarely become so by being educated as outlaws. As a result of all that, we have much reason for, and little reason against, bringing up children within the ethical world we inhabit, and if we succeed they themselves will see the world from the same perspective.” (Williams 1985, 48)

So the underdetermination of human nature for ethics becomes a question of degree, and the precepts of traditional morality can still be seen as a best bet for a well-lived life.

But if we base traditional morality merely on common human needs, then there is a further question that arises about whether this can fully make sense of the normative authority that the precepts of traditional morality seem to possess, especially those that relate to what I have described as sacred values. For one thing, this appears to express an instrumentalized view of such values; i.e., the appeal is to their usefulness in serving common human needs rather than their inherent demandingness. ${ }^{18}$ Furthermore, given these common human needs and related desires and emotional responses are the result of evolutionary and cultural processes that could have been otherwise, we might worry, as Williams does, that "[this] sense of contingency [is] in tension with something that our ethical ideas themselves demand, a recognition of their authority". The normative authority of ethics, as traditionally understood, seems to carry with it a sense of necessity that is at odds with seeing our ethical beliefs as radically contingent. For instance, we experience it as a non-contingent fact that we ought never to kill intentionally an innocent human being and that we ought to act with kindness rather than cruelty towards others because of their special dignity or sacred value. In other words, this is true in any possible world where there are human beings. To make these precepts contingent on our common human needs and related desires and emotional responses means to accept a significantly reduced conception of normative authority. The only sort of ethical necessity that is possible here, it seems, is that which has to do with how certain ethical commitments structure our identity such that following these commitments is necessary for maintaining this identity. As Hampshire puts it:

18 See n. 6 for an example of this sort of instrumentalized approach to 'sacred values'. 
"I believe that critical reflection may leave the notion of absolutely forbidden, because absolutely repugnant, conduct untouched. [...] [There] may be reflective reasons, in the sense that one is able to say why the conduct is impossible as destroying the ideal of a way of life that one aspires to and respects, as being, for example, utterly unjust or cruel or treacherous or corruptly dishonest.” (Hampshire 1983, 90)

David Wiggins, who is also a proponent of traditional morality (or "ordinary morality", ${ }^{19}$ as he calls it), similarly writes: "We feel bound. But why reasonbound? Why not say we feel bound by our moral nature, i.e., bound by those sentiments without which (we have concluded, if we feel bound by obligation) we should not recognize ourselves?" (Wiggins 1995, 310; cf. 2006, 135, 234-235) Central to our "moral nature", Wiggins maintains, is a solidarity that is connected to the "indefinable influence" that other human beings have upon us (recall Diamond's comments above about solidarity and its connection to "the sense of mystery surrounding our lives"). ${ }^{20}$ And it is also connected with our "primitive aversion from acts that appear as a direct assault by one personal being upon another, acts such as murder, wounding, injury, plunder, pillage, the harming of innocents, the repaying of good with gratuitous evil, false witness [...]. [Such] acts pass beyond the valuations bad, disappointing, [...] lamentable, and trespass onto the ground marked forbidden." (Wiggins 2006, 246-247; cf. 11, 222)

Here we seem to be in the realm of sacred value. However, as we see, Wiggins wants to explain the binding force (i.e., "practical necessity" or normative authority) of moral considerations primarily in terms of our "moral nature", i.e., in terms of certain moral sentiments, rooted in solidarity, "without which [...] we should

19 Wiggins 2006, 3-4 \& ch. 9. Wiggins is a 'genealogist' is the mold of Hume "who is [...] committed to that which he explains-prepared that is, when enough of the pieces are falling into place, to try to vindicate most (but certainly not all) of the attitudes and convictions he seeks to explain" (165; cf. 230-231, 236). This contrasts with the intended destructive uses of genealogy by Nietzsche and, following him, Williams. I think Aristotle can similarly be seen as a 'vindicatory genealogist'. As Martha Nussbaum has discussed, Aristotle's philosophical methodology begins from the 'appearances' (phainomena), which includes taking account of what 'the many' and 'the wise' have thought about a particular topic (e.g., 'What is virtue?', 'What is happiness?', etc.), and then tries to 'save' what is true in them. Aristotle "insists that he will find his truth inside what we say, see, and believe, rather than 'far from the beaten path of human beings' (in Plato's words) 'out there"' (Nussbaum 2001[1986]), 243).

20 The phrase 'indefinable influence' is Simone Weil's. She characterizes it as follows: "Anybody who is in our vicinity exercises a certain power over us by his very presence, and a power not exercised by him alone, that is the power of halting, repressing, modifying each movement that our body sketches out. If we step aside for a passer-by on the road, it is not the same thing as stepping aside to avoid a bill-board.” (quoted in Wiggins 2006, 243) 
not recognize ourselves”. Moreover, in a Humean fashion, Wiggins does not take this to mean that we are "reason-bound". He elaborates:

"such practical necessity can give $x$, who feels it, a reason, yet this can be a reason one cannot without begging the question convert into a demonstration of someone else's irrationality where they are unimpressed by the considerations that create for $x$ a necessity" (Wiggins 1995, 310-311, n. 12).

Wiggins does go further elsewhere in maintaining that not only are there certain moral sentiments, rooted in solidarity, "without which [...] we should not recognize ourselves", but some of these moral sentiments are the conditions for the possibility of any ethical life whatsoever, and hence we should expect some general convergence on them insofar as we go in for an ethical life at all. In particular, our moral sentiments regarding "the utterly forbidden" concern something the violation of which "menaces the very fabric of the ethical by threatening to destroy the basis of the ethical in solidarity" (Wiggins 2006, 248). ${ }^{21}$ Wiggins contends: "Human solidarity [...] is not an ordinary human pursuit. Its role is to condition, to civilize, and to humanize human pursuits.” (Wiggins 2008, 18) So, we might say then that ethical theories such as utilitarianism and liberal Kantianism (i.e., autonomy-centered ethics) still depend upon such human solidarity for whatever validity they possess, but they end up undermining this very human solidarity in not giving adequate place to "the utterly forbidden". Recall Lewis: “The rebellion of new ideologies against the Tao is a rebellion of the branches against the tree: if the rebels could succeed they would find that they have destroyed themselves."

I think there is a lot that is compelling about Wiggins's account, especially his claim that solidarity and its connection with the utterly forbidden are the conditions for the possibility of any viable ethical life whatsoever. However, there are a couple of worrying features. One concerns the direction of explanation with regard to the binding force (or normative authority) of moral considerations. Although Wiggins affirms that there is an integral role played by both the subject side and object side of our experiences of "non-instrumental" values and we can say that certain responses (e.g., solidarity) and properties of objects (e.g., the properties that make up a human being) are "made for one another" granted one has a certain moral nature and acquired moral self-understanding (see Wiggins 1998[1987], 106-107, 193-194, 198-199, 207; 2006, pt. III), nevertheless, he explains the binding force of moral considerations primarily in terms of the subject of experience rather than the object. As we have seen, it is explained in terms of our "moral nature" and the moral sentiments "without which [...] we should

21 Hampshire holds a similar view; see Hampshire 1983, 89. 
not recognize ourselves". But our experience of sacred values seems to give priority to the object side in regarding things of sacred value (e.g., human beings) as being intrinsically reverence-worthy and making normative demands upon us, and there seems to be something deflationary in explaining the binding force of sacred values or the utterly forbidden primarily in terms of the subject side. ${ }^{22}$

The second worry, which is related to the first, concerns Wiggins's abdication of the idea that we are reason-bound such that what count as moral considerations for someone $[x]$ "cannot without begging the question convert into a demonstration of someone else's irrationality where they are unimpressed by the considerations that create for $x$ a necessity". Thus, although human beings may generally be constituted with a moral nature and educated such that they are impressed by such consideration, if they do not happen to be so constituted and educated, then there is nothing more to be said. There is a concession to contingency here and with it a loss of a certain kind of moral authority that seems presupposed in common experiences of sacred values, where, as mentioned above, we experience it as a non-contingent fact, e.g., that we ought never to kill intentionally an innocent human being and that we ought to act with kindness rather than cruelty towards others. To make ethical (or practical) necessity contingent upon a moral self-conception-where ethical commitments structure our identity and so following these commitments is necessary for maintaining this identity-means, as mentioned above, accepting a significantly reduced conception of normative authority.

So what are the prospects for affirming a stronger sense of normative authority of the sort that seems actually to be presupposed in our experience of sacred values? We should consider here the work of John McDowell. He writes:

\begin{abstract}
"The ethical is a domain of rational requirements, which are there in any case, whether or not we are responsive to them. We are alerted to these demands by acquiring the appropriate conceptual capacities. When a decent upbringing initiates us into the relevant way of thinking, our eyes are opened to the very existence of this tract of the space of reasons. Thereafter our appreciation of its detailed layout is indefinitely subject to refinement, in reflective scrutiny of our ethical thinking.” (McDowell 1994, 82; my emphasis)
\end{abstract}

McDowell does not speak of sacred values, but instead focuses on the value of "the noble" (which can "silence" other considerations; see McDowell 1998, 16-18, 55-

22 It should be clear that Wiggins's position is not any sort of subjectivist view according to which value claims are either a mere expression of attitude (emotivism) or a mere projection of our psychological states onto the world (projectivism), nevertheless, he still calls it a kind of subjectivism in that "the properties in question are explained by reference to the reactions of human subjects" (Wiggins 1998[1987], 195). 
56, 90-93). However, on the basis of the preceding discussion of sacred values, I think his account can and should be extended to include the ways in which "our eyes are opened to" the demands of the sacred (i.e., the reverence-worthy), such as through the example of saintly love or the experience and practice of solidarity. Indeed, I would say that this is at the "root of the ethical" (to borrow Wiggins's way of putting it). But, as we see here, this opening of our eyes to the demands of the sacred requires a particular kind of ethical formation or upbringing (or Bildung, as McDowell also refers to it), and this means that we must be immersed in a particular tradition-informed moral community.

McDowell defends the idea that "immersion in a tradition might be a respectable mode of access to the real" (McDowell 1994, 98), where "the real" that is particularly at issue is a kind of ethical reality that is "there in any case, whether or not we are responsive to [it]". He goes on to fill out this idea of immersion in a tradition as follows:

\begin{abstract}
"[It] is not even clearly intelligible to suppose a creature might be born at home in the space of reasons. Human beings are not: they are born mere animals, and they are transformed into thinkers and intentional agents in the course of coming to maturity. [...] In being initiated into a language, a human being is introduced into something that already embodies putatively rational linkages between concepts, putatively constitutive of the layout of the space of reasons, before she comes on the scene. This is a picture of the space of reasons as an already going concern [...]. [A] natural language [...] serves as a repository of tradition, a store of historically accumulated wisdom about what is a reason for what. The tradition is subject to reflective modification by each generation that inherits it. Indeed, a standing obligation to engage in critical reflection is itself part of the inheritance. [...] But if an individual human being is to realize her potential of taking her place in that succession, which is the same thing as acquiring a mind, the capacity to think and act intentionally, at all, the first thing that needs to happen is for her to be initiated into a tradition as it stands." (125-126)
\end{abstract}

There are several important things to comment on here. First of all, this passage makes it clear that we only achieve what is most admirable and distinctive in our humanity through our upbringing within a particular tradition-informed cultural life. ${ }^{23}$ Secondly, as mentioned above, we do not begin by trying to 'reinvent the wheel' in the ethical life but rather, as we see here, by being "initiated into a tradition as it stands" in order to learn from "the best which has been thought and

23 Consider here the following from Edwin Muir in his autobiography: "I think that if we examine our lives, we will find that most good has come to us from the few loyalties, and a few discoveries made many generations before we were born, which must always be made anew. [...] As I look back on the part of the mystery which is my own life, my own fable, what I am most aware of is that we receive more than we can ever give; we receive it from the past, on which we draw with every breath.” (used as an epigraph in Norris 1993) 
said" (Arnold 2006[1869], 5). We also learn from the best ethical exemplars of a tradition, as we see in Aristotle's appeal to the person of practical wisdom. ${ }^{24}$

The kind of learning at issue here requires a significant degree of 'docility', i.e., teachability, where we are dispositionally open to learning from the "store of historically accumulated wisdom about what is a reason for what" as this comes to us from parents and other family members, teachers, exemplars, elders, ancestors, and our community and its laws and customs. ${ }^{25}$ But this is not the end of the story: although we begin from a certain degree of passivity, as we learn and mature we become active participants in our tradition-informed cultural life-as a living tradition-and we may come to criticize and seek to reform parts of our inherited form of life that seem defective. Indeed, as McDowell says, "a standing obligation to engage in critical reflection is itself part of the inheritance". The critical test for any such form of life is whether it can coherently be seen-by our best lights when we are engaged within it-as best revealing our ethical demands and as best enabling us to live well and do well. ${ }^{26}$ What we cannot do is completely throw off all tradition-informed cultural life since this provides the means by which ethical demands come into view in the first place and by which we can live well and do well. Thus, when something seems defective in our tradition-informed cultural life, we will need to make piecemeal modifications, where we seek through practical reason to overcome what is problematic while also conserving what is good. ${ }^{27}$

What is important to see is that there is here a possibility of a robust conception of ethical convergence. The key idea is that insofar as a particular traditioninformed cultural life is in good order we should expect that it will converge, within the space of reasons, upon the recognition of ethical demands (e.g., demands of the sacred) that are "there in any case, whether or not we are responsive to them", and hence immersion in a tradition can be regarded as a mode of access to "the real". One might question whether such a conception of ethical demands as being "there in any case, whether or not we are responsive to them" depends upon a teleological metaphysic according to which the universe expresses "ulti-

24 See, e.g., Nicomachean Ethics, VI.11, 1143b11-14.

25 Cf. Nicomachean Ethics, X.9, 1179b23-33; II.1, 1103b23-5; I.4, 1095b7-8.

26 Drawing on the metaphor of Neurath's ship, which has to be rebuilt while at sea, McDowell writes: "[One] can reflect only from the midst of the way of thinking one is reflecting about. So if one entertains the thought that bringing one's current ethical outlook to bear on a situation alerts one to demands that are real, one need not be envisaging any sort of validation other than a Neurathian one. The thought is that this application of one's ethical outlook would stand up to the outlook's own reflective self-scrutiny." (McDowell 1994, 81)

27 Recall Lewis: "Some criticism, some removal of contradictions, even some real development, is required. [...] [The] Tao admits of development from within.” 
mate moral purposes". ${ }^{28}$ Perhaps this is so, and if one is not able to affirm such a view, then it seems that the best we can do is something like Wiggins's account of the moral life rooted in our moral nature. However, as I have discussed, Wiggins's account seems somewhat deflationary and our experience of sacred values seems to point us in the direction of something like McDowell's account of ethical demands that are "there in any case". My aim here is not to decide this issue but rather to show what can be said in favor of traditional morality and its convergence thesis. I have made the case that without proper recognition of the sort of sacred values affirmed by traditional morality we distort the moral life and can end up undermining it altogether, and thus we should expect that a moral life in good order will in fact converge upon a common morality, even if there are differences in the details still to be worked out.

Acknowledgment: I thank Fiona Ellis, John Cottingham, Tom Angier, and Anton Leist for very helpful comments on this essay.

\section{References}

Anscombe, G. E. M. (1958), Modern Moral Philosophy, in: Philosophy 33, 1-19

- (2008), Faith in a Hard Ground, ed. M. Geach/L. Gormally, Charlottesville

Aristotle (1999[c. 325 BC]), Nicomachean Ethics, trans. T. Irwin, $2^{\text {nd }}$ ed., Indianapolis

Arnold, M. (2006[1869]), Culture and Anarchy, Oxford

Benatar, D. (2002), Two Views of Sexual Ethics: Promiscuity, Pedophilia, and Rape, in: Public

Affairs Quarterly 16, 191-201

Burke, E. (2009[1782]), Speech on the Representation of the Commons in Parliament, in: Edmund Burke: Selected Writings and Speeches, ed. P. J. Stanlis, New Brunswick

Cottingham, J. (2009), The Good Life and the 'Radical Contingency of the Ethical', in: Reading Bernard Williams, ed. D. Callcut, New York

Diamond, C. (1978), Eating Meat and Eating People, in: Philosophy 53, 465-479

- (1991), The Importance of Being Human, in: Human Beings, ed. D. Cockburn, Cambridge

- (Forthcoming), The Problem of Impiety, in: Spirituality and the Good Life: Philosophical Approaches, ed. D. McPherson, Cambridge

Donagan, A. (1977), The Theory of Morality, Chicago

Dworkin, R. (1993), Life's Dominion: An Argument about Abortion, Euthanasia, and Individual Freedom, New York

- (2013), Religion without God, Cambridge/MA

28 The phrase 'ultimate moral purposes’ is from Nietzsche 1974 (1882/1887), §357. On the need for some metaphysical or ontological background picture to support such a moral phenomenology, see Taylor 1989, pt. 1; 2003; 2011; McPherson 2015. 
-/T. Nagel/R. Nozick/J. Rawls/T. Scanlon/J. J. Thomson (1997), Assisted Suicide: The Philosophers' Brief, in: The New York Review of Books

Haidt, J. (2012), The Righteous Mind: Why Good People Are Divided by Politics and Religion, New York

Hampshire, S. (1983), Morality and Conflict, Cambridge/MA

Hayek, F. A. (1988), The Fatal Conceit: The Errors of Socialism, Chicago

Gaita, R. (1991), Good and Evil: An Absolute Conception, New York

- (1998), A Common Humanity: Thinking about Love and Truth and Justice, New York

Goldman, A. (1977), Plain Sex, in: Philosophy \& Public Affairs 6, 267-287

Kekes, J. (1998), A Case for Conservatism, Ithaca

Keown, J. (2012), The Law and Ethics of Medicine: Essays on the Inviolability of Human Life, Oxford

Laing, J. A. (1997), Innocence and Consequentialism: Inconsistency, Equivocation and Contradiction in the Philosophy of Peter Singer, in: Human Lives: Critical Essays on Consequentialist Bioethics, ed. D. S. Oderberg/J. A. Laing, Basingstoke

Lewis, C. S. (1944), The Abolition of Man, New York

MacIntyre, A. (2007[1981]), After Virtue, $3^{\text {rd }}$ ed., Notre Dame

Marx, K./F. Engels (2000[1848]), The Communist Manifesto, in: Karl Marx: Selected Writings, ed. D. McLellan, $2^{\text {nd }}$ ed., Oxford

McDowell, J. (1994), Mind and World, Cambridge/MA

- (1998), Mind, Value, and Reality, Cambridge/MA

McPherson, D. (2015), Cosmic Outlooks and Neo-Aristotelian Virtue Ethics, in: International Philosophical Quarterly 55, 197-215

Nietzsche, F. (1974[1882/1887]), The Gay Science, trans. W. Kaufmann, New York

Norris, K. (1993), Dakota: A Spiritual Geography, New York

Nussbaum, M. (2001[1986]), The Fragility of Goodness: Luck and Ethics in Greek Tragedy and Philosophy, updated edition, Cambridge

Oderberg, D. S. (2000a), Moral Theory: A Non-Consequentialist Approach, Oxford

- (2000b), Applied Ethics: A Non-Consequentialist Approach, Oxford

Plato (1997[c. 375 BC], Symposium, trans. A. Nehamas/P. Woodruff, in: Plato: Complete Works, ed. J. M. Cooper, Indianapolis

Primoratz, I. (2001), Sexual Morality: Is Consent Enough? In: Ethical Theory and Moral Practice 4, 201-218

Scruton, R. (1986), Sexual Desire, New York

- (1996), An Intelligent Person's Guide to Philosophy, New York

- (2006), A Political Philosophy: Arguments for Conservatism, London

Singer, P. (1993), Practical Ethics, Cambridge

- (1995), Rethinking Life and Death: The Collapse of Our Traditional Ethics, New York

Taylor, C. (1989), Sources of the Self: The Making of Modern Identity, Cambridge/MA

- (2003), Ethics and Ontology, in: The Journal of Philosophy 100, 305-320

- (2011), Recovering the Sacred, in: Inquiry 54, 113-125

Thomson, J. J. (1971), A Defense of Abortion, in: Philosophy \& Public Affairs 1, 47-66

Wiggins, D. (1995), Categorical Requirements: Kant and Hume on the Idea of Duty, in: Virtues and Reasons, ed. R. Hursthouse/G. Lawrence/W. Quinn, Oxford

- (1998[1987]), Needs, Values, Truth: Essays in the Philosophy of Value, $3^{\text {rd }}$ ed., Oxford

- (2001), Sameness and Substance Renewed, Cambridge

- (2006), Ethics: Twelve Lectures on the Philosophy of Morality, Cambridge/MA 
- (2008), Solidarity and the Root of the Ethical, The Lindley Lecture, The University of Kansas, URL: https://kuscholarworks.ku.edu/handle/1808/12420

Williams, B. (1985), Ethics and the Limits of Philosophy, Cambridge/MA

- (2002), Truth and Truthfulness, Princeton 